\title{
Implementing the National Council of Teachers of Mathematics Standards: A slow process
}

\author{
Joseph M. Furner, Ph.D. \\ Florida Atlantic University \\ email: jfurner@fau.edu
}

\begin{abstract}
The purpose of this study was to look at inservice teachers' pedagogical beliefs about the National Council of Teachers of Mathematics Standards (1989 \& 2000). The Standards' Belief Instrument (Zollman and Mason, 1992) was administered on teachers. An ANOVA was used to look for a significant difference between teachers with five years or less experience of teaching mathematics, and those with more than five years teaching experience. One expectation was that teachers who are recent graduates of teacher education programmes may have more training on the NCTM Standards. Although there were no statistically significant differences between the two groups, this study did support the expectation. Current training with in-service teachers shows that many of the teachers are familiar with neither the National Council of Teachers of Mathematics nor their Standards. It seems then from this study that the implementation process of the NCTM Standards, and perhaps any standards or best practices and new curriculum implementation, is very sluggish.
\end{abstract}

\section{Introduction}

In recent conversations with a group of in-service mathematics teachers, the author found that only one out of 13 of the teachers in the group was familiar with the NCTM Standards (1989 \& 2000). This article concerns a study conducted with math teachers to determine their pedagogical knowledge and beliefs about the NCTM Standards in hopes of promoting a more effective implementation of the NCTM Standards.

A changing and economically competitive world has predicated a need for reform in mathematics education. Research conducted by the Board of Directors of the National Council of Teachers of Mathematics (NCTM) in the mid 1980s indicated that the mathematics curricula for elementary and secondary schools in the United States were not sufficient. The NCTM Standards came about as an extension of Americans' responses to the demand for change. NCTM felt that a set of standards needed to be identified in order to improve nationwide test scores in the area of mathematics. In 1989 the National Council of Teachers of Mathematics published Curriculum and Evaluation Standards aimed at reforming school mathematics (NCTM, 1989). The NCTM's vision focused on encouraging students, probing for ideas, and carefully judging the maturity of a student's thoughts and expressions (NCTM, 1989). Implementation of the standards is essential, since current and/or previous teaching practices in mathematics classrooms often dos not provide for sufficient critical thought. Since teachers tend to teach the way they were taught themselves, Sarason (1993) believes that any reform in education must begin with teacher training. NCTM published their new version of the math standards in 2000. Practising mathematics teachers and pre-service teachers thus need to be trained to implement these standards. Furthermore, if schools are to improve the quality of teaching mathematics, then both the teachers and teacher educators to need to believe implicitly in the value of these Standards.

The purpose of this study was to compare teachers with five years or less teaching experience with teachers who have five or more years of teaching experience, using the Standards' Belief Instrument (SBI) (Zollman and Mason, 1992), in order to determine a measure of teachers' beliefs about the use of the NCTM Standards. The research hypothesis states the following: There will be a significant difference in the Standards' Beliefs Instrument scores of teachers with five years or less of teaching experience when compared to teachers with five or more years of experience.

Research in mathematics education (Bush, Lamb, \& Alsina, 1990; Fullan, 1983; Kessler, 1985; McGilliard, 1983; Silver, 1985; Thompson, 1984) indicates teaching behaviour is affected by teacher beliefs concerning mathematics. Thompson (1984) found that mathematics teachers' opinions, beliefs and inclinations swayed their instructional practices. Many inappropriate teaching methods can thus be attributed to teachers' tenets about teaching (FerriniMundy, 1986). The results of the present study can be used to determine the potential for changing 
teachers' beliefs in order to improve their teaching practices.

For the purpose of this study, a belief was defined as "a judgement of the credibility of a conceptualisation. Credibility of a conceptualisation has to do with whether one accepts, rejects, or suspends judgement concerning a set of concepts and the interrelationships among these concepts" (Reyes, 1987, p.10). This same definition was used by the creators of the SBI.

The following are considered to be limitations of the study: (a) This study is limited to seventh and eighth grade teachers in the southeast and thus, may not be generalisable to other settings; (b) The relatively small sample size limits the generalisability of this study; (c) The honesty of participants' answers to questions is assumed; (d) It cannot be ascertained whether teachers actually used the NCTM Standards as only their attitudes and beliefs were measured using the SBI.

\section{Literature Review}

Research on mathematics teachers' beliefs on the use of and need for the NCTM Standards was introduced by Zollman and Mason in 1992, after they designed and tested an instrument that they named the Standards' Beliefs Instrument (SBI) (Zollman \& Mason, 1992). The SBI has a myriad of implications for teaching mathematics. In order to provide a basis for understanding the implications for teaching the NCTM Standards, research related to mathematics teacher preparation, teacher beliefs, attitudes towards mathematics education, and the implementation of the NCTM Standards have been included. Zollman and Mason (1992) contend that an important relationship exists between a teacher's beliefs and that teacher's own style of teaching. Therefore, a wide acceptance of the NCTM Standards could hinge on a teacher's own beliefs.

Researchers continue to emphasize the need to reform teacher education to promote a corresponding transformation in mathematics instruction in today's schools (Lubienski, 2000a). Apple (1992), who sees some aspects of the Standards as problematic, contends that the present conservative social context will determine the use to which the NCTM Standards are put to in practice. He expresses concern that in the U.S., unequal school finance policies in providing technologically rich classroom environments will result in educational stratification which in itself may have an impact on the full implementation of the NCTM Standards. Sarason (1993) believes that in the case of reform, educators need to first focus on preparing teachers differently. The NCTM Standards can act as a catalyst for this preparation (NCTM, 1989). The pre-service and continuing education of teachers of mathematics should provide them with opportunities to examine and revise their assumptions about how mathematics should be taught, and how students learn mathematics (NCTM, 1989, p. 160). Gadanidis (1994) claims that teachers must have an understanding of the NCTM Professional Standards for Teaching Mathematics (1991), which state that "the final success for any teacher is the integration of theory and practice."

O'Laughlin (1990) found that beginning teachers maintain definite beliefs with regard to knowing, learning, and teaching. This often leads them to endorse didactic approaches, with the teacher acting as the primary conveyer of knowledge. A teacher's beliefs about students' abilities greatly influence the decisions the teacher makes about the learning environment (Lubinski, 1994). Lubinski (1994) feels that teachers who believe that the content of the mathematics in their classroom is guided by the textbook make different decisions than teachers who believe that the content of the mathematics is guided by students' interest and ability. Research indicates that teachers' knowledge as well as beliefs is related to the instructional decision-making process (Fennema \& Franke, 1992; Parares, 1992; Thompson, 1992). Therefore, what a teacher believes about teaching and learning mathematics and what a teacher knows about the content, methods, and materials available to teach mathematics, influence the teacher's instructional decisions.

Research has shown that it is critical for secondary mathematics teachers to have strong mathematical knowledge and a positive attitude toward mathematics and teaching, as well as an alignment with proper pedagogical beliefs (Stigler \& Hiebert, 1999; Furner, 1996; Kerr \& Lester, 1982; Meyer, 1980). It is believed that mathematics education majors have not been exposed to enough alternative teaching methods to be capable of teaching mathematics with an emphasis on meaning (Ball \& Wilson, 1990). Ball and Wilson (1990) discovered that preservice secondary mathematics teachers often lack sufficient mathematical understanding to teach the subject effectively. Farrell and House (1994) believe that prospective mathematics teachers must construct knowledge abut teaching, and in the process must frequently reconstruct their knowledge of mathematics. In 1991 the National Council of Teachers of Mathematics along with the Association for Supervision and Curriculum Development, published A Guide for Reviewing School 
Mathematics Programs. In this document they claimed that in order to have high-quality mathematics programmes, teachers of mathematics must be well prepared, process and demonstrate positive attitudes, continue to grow professionally, and be actively involved in educational issues that affect the quality of their students' learning (NCTM \& ASCD, 1991).

The research that exists on the implementation of the NCTM Standards is immense. The NCTM Standards presents a picture of a classroom instruction which differs from present practice in secondary schools. The implementation of the Standards involves a restructuring of mathematics instruction, which involves the implementation of the NCTM Standards for both pre-service and inservice mathematics teachers (Parker, 1991). One professor of secondary mathematics education found that she needed to change her teaching pedagogy in order to incorporate NCTM Standards. She found that even well-prepared mathematics students experienced a great deal of trauma as a result of learning mathematics in new ways. The professor modelled her teaching on the NCTM Standards. The activities included cooperative problem solving with manipulatives such as geoboards, tangrams, algebra tiles, technology, etc. (Farrell \& House, 1994). Farrell and House (1994) contended that teaching mathematics methods students by incorporating the NCTM Standards helped the students learn mathematics in a new way. The process thus acted as a model for the future mathematics educators to use in their own teaching. The Standards documents recommend a departure from conventional forms of instruction and evaluation, as well as a more holistic approach to conveying the content knowledge. Principles and Standards for School Mathematics (NCTM, 2000) highlight six underlying principles which include: (a) Equity - high expectations for all students; (b) Curriculum - coherent and articulated across K-12; (c) Teaching - what students know and what they need to learn - effective pedagogy; (d) Learning for understanding and connecting to prior knowledge; (e) Assessment - support learning and give information to teacher and learner; and (f) Technology - what is taught and enhances learning.

Some researchers believe that there must be a link between pedagogy and mathematics, and that during pre-service teacher training the students must have a hands-on approach in their math methods course in order to fully implement the Standards (Cooney \& Friel, 1992). Lubienski (2000b) feels that the changing mathematics curricula and pedagogy can also remove or add barriers for lower social economic status students and this needs to be taken into consideration when teachers are teaching mathematics. As Edgerton (1992) contends, the implementation of the Standards demands a great deal of teacher training if the Standards are to be fully incorporated in mathematics classrooms. For now, the Standards are slowly being implemented in a fragmented manner.

This review of the literature has provided information concerning the attitudes, content knowledge, pedagogy, beliefs and preparation of inservice and pre-service teachers with regard to the implementation of the NCTM Standards. The research indicates that a large body of knowledge exists in regards to how teacher's beliefs, knowledge, and pedagogy affect the way in which they actually teach. The NCTM Standards address the issues facing today's young people, and provide a way to make mathematics more meaningful. They contend that these issues must be considered by the teacher. The present study attempted to add to this body of knowledge by investigating the pedagogical beliefs, mathematical knowledge, mathematics teacher training and implementation of the NCTM Standards by both in-service and pre-service mathematics teachers.

\section{Research Methods}

The purpose of this study was to determine whether mathematics teachers who have recently graduated and have started teaching are more familiar with and believe more strongly in incorporating the NCTM Standards in their teaching. The following null hypothesis was tested: There is no significant difference between the Standards' Beliefs Instrument scores of teachers with less than five years of teaching experience and those of teachers with five years or more of teaching experience.

\section{Description of the Sample}

The population for this study came from seventh and eighth grade teachers in the southeast of the United States. The population of the city was 78,732 at the time of data collection. The population of the entire county area is 153,677 (Statistics from Chamber of Commerce, October, 1995). The city has an industrial economic base as well as a large research university. The school system is quite large, with three middle schools. One houses all eighth graders, one all seventh graders and the other all sixth graders. The seventh and eighth grade middle schools provide approximately half of the population for this study. The combined enrolment in the two city middle schools is 1,513 students. The school system used in the study has three middle schools. 
One houses seventh and eighth grade students only, a second houses seventh, eighth, and ninth grade students and the third houses sixth, seventh, and eighth grade students. There are two other schools which house seventh through twelfth grade students. There is a population of 2,670 seventh and eighthgrade students. Forty-nine teachers were invited to participate in this study.

The Standards' Belief Instrument: The Standards' Belief Instrument (SBI) (Zollman and Mason, 1992) was used to assess the mathematics teachers' beliefs concerning the Standards. The SBI consists of sixteen questions from the NCTM Standards which appeared in the NCTM's publications, "Curriculum and Evaluation Standards for School Mathematics" and "Principles and Standards for School Mathematics.” The SBI uses a 16-item, four-choice Likert type scale. The SBI has a Spearman-Brown reliability of .79 and an alpha coefficient of .803 as reported by Zollman and Mason (1992). A panel of experts affiliated with NCTM (Zollman and Mason, 1992) found the instrument to have construct validity. The Standards' Belief Instrument (SBI) was specifically developed by Zollman and Mason to measure teachers' beliefs about the NCTM "Curriculum and Evaluation Standards" using items representative of beliefs about the Standards. Items for the SBI were randomly chosen from several levels of the Standards to be representative of the Standards overall. The sixteen items from the SBI were either nearly direct quotes from the Standards or an inverse of a direct quote from the Standards. Zollman and Mason provide a guide in their article, "The Standards' Belief Instrument (SBI): Teachers' beliefs about the NCTM Standards," citing the pages in the standards from which each question was formulated. The SBI used in this study appears in Appendix A. A demographic questionnaire was also used to collect data (see Appendix A).

\section{Collection of Data}

Prior to administering the instrument, the researcher selected a total of 49 possible seventh and eighth grade teachers, using school computerised records, to participate in the study. A cover letter and request for permission from each of the 49 teachers and the eight school principals was sent out, inviting them to participate in the study. It was stressed in the cover letter than no attempt would be made to determine the attitudes of students toward any individual teacher or the teachers in a particular school. All teachers involved in the study were assured that data would be treated strictly as stated in the hypothesis.
Directions for completing the SBI appeared on the instrument. Using optical scan response sheets, the teachers were directed to darken the appropriate circles for all responses. Teachers were told that all surveys would be anonymous and the responses would not be seen by any principal. In all, 41 teachers participated in the study.

The teachers' responses to the SBI were analysed using computational formulas given by Zollman and Mason (1992). A point rating was assigned for each possible response. In determining each individual teacher's raw score, survey items that were negatively stated were scored exactly as marked: $1=$ =strongly disagree, $2=$ disagree, $3=$ agree, and $4=$ strongly agree. Positively stated items were assigned points opposite to the above scheme: $4=$ =strongly disagree, 3 =disagree, $2=$ =agree, and $1=$ strongly agree. A scaled score was determined by summing the scores of all items in the scale. As suggested by Zollman and Mason (1992), items left unanswered were assigned the mean response over all teachers in the norming sample. If teachers answered less than one half of the instrument, that teacher's survey was not included in the analysis of data.

After data for each group listed in the hypothesis had been collected and organised, the Null Hypothesis was tested using an ANOVA procedure. Tables reflecting the population size, means, variance, and standard deviations of each group on each dimension were compiled as part of this analysis. The discriminant function analysis was run using the Statistical Analysis System (SAS) software package (SAS Institute, Inc., 1985). A $p<.05$ level of significance, was used to determine whether a significant difference existed for the hypothesis.

\section{Presentation and Analysis of Data}

The purpose of this study was to consider the effects of seventh and eighth grade mathematics teachers' beliefs about the NCTM Standards, on their teaching practice, based on length of time they had been teaching.

Of the 49 teachers asked to participate in the study, 41 actually completed the teacher survey, along with one class of their students. Some special education teachers who teach math and a few ninth grade teachers were given the survey by the researcher without the exact status of their grade level and/or level of ability being ascertained. There were 34 female teachers and seven male teachers who participated in this study. 
Testing of the Research Null Hypothesis

Null Hypothesis: There is no significant difference between the Standards' Beliefs Instrument scores of teachers with five or less years of teaching experience and those of teachers with more than five years of teaching experience. or more years (42.58). It must be noted here that this sample of 41 teachers rendered only 8 teachers with less than five years of teaching experience as opposed to the 33 teachers who fell into the category of teachers teaching five or more years.

The researcher also compiled some additional

\begin{tabular}{|l|c|c|c|c|c|}
\hline Source & df & SS & MS & F value & Critical F \\
\hline Model & 1 & 41.845 & 41.845 & 2.82 & 0.1012 \\
\hline Error & 39 & 578.936 & 14.845 & & \\
\hline C. Total & 40 & 620.780 & & & \\
\hline Years Teaching Category & 1 & 41.845 & 41.845 & 2,82 & 0.1012 \\
\hline
\end{tabular}

Table 1: Analysis of Variance Procedure for the Null Hypothesis

An ANOVA was completed to test this null hypothesis at the $\mathrm{p}<.05$ level of significance (See Table 1). The assumptions of (a) random samples, (b) normality, (c) homogeneity of variance, and (d) independent groups were met. In comparing the SBI scores, teachers were placed into two categories: category 1 consisted of teachers teaching five years or less and category 2 consisted of teachers teaching more than five years. The results of this test indicated no significant difference with a $\mathrm{p}$ value of 0.1012 and an $F$ value of 2.82. Thus, the null hypothesis was not rejected. Interestingly, teachers with less than five years of teaching experience (eight teachers) had a slightly higher mean score (45.13) than the teachers teaching (33 teachers) five survey statistics collected from both the groups data in this study. The statistics collected were from the demographic portion of the teacher survey as well as the instrument itself.

Table 2 provides a frequency of the teachers' responses to the SBI. The table reflects how the two groups of teachers rated each of the sixteen items on the SBI (see Appendix A). It was found that teachers' scores on the SBI ranged from a low of 31 to a high of 52 .

No significant difference was found in teachers who have taught less than five years over teachers who have taught five years or more regarding their beliefs about the NCTM Standards. However, teachers who are most recent graduates of teacher

\begin{tabular}{|c||c|c|c|c|c|c|c|c|}
\hline \multirow{2}{*}{ Item } & \multicolumn{2}{|c|}{ Strongly Disagree } & \multicolumn{2}{c|}{ Disagree } & \multicolumn{2}{c|}{ Agree } & \multicolumn{2}{c|}{ Strongly Agree } \\
\cline { 2 - 9 } & 5 or $<$ & $>5$ & 5 or $<$ & $>5$ & 5 or $<$ & $>5$ & 5 or $<$ & $>5$ \\
\hline \hline-1 & 3 & 8 & 3 & 14 & 2 & 8 & 0 & 3 \\
\hline+2 & 0 & 0 & 0 & 1 & 2 & 22 & 6 & 10 \\
\hline+3 & 0 & 0 & 0 & 0 & 1 & 18 & 7 & 15 \\
\hline+4 & 1 & 0 & 1 & 1 & 4 & 20 & 2 & 12 \\
\hline-5 & 4 & 7 & 2 & 21 & 2 & 5 & 0 & 0 \\
\hline+6 & 1 & 1 & 1 & 0 & 3 & 21 & 3 & 11 \\
\hline-7 & 3 & 3 & 4 & 20 & 0 & 8 & 1 & 2 \\
\hline-8 & 0 & 1 & 1 & 8 & 5 & 21 & 2 & 3 \\
\hline-9 & 0 & 0 & 0 & 1 & 6 & 22 & 2 & 10 \\
\hline-10 & 0 & 1 & 3 & 0 & 5 & 23 & 0 & 9 \\
\hline-11 & 0 & 0 & 3 & 5 & 5 & 23 & 0 & 5 \\
\hline-12 & 0 & 0 & 1 & 4 & 7 & 26 & 0 & 3 \\
\hline+13 & 0 & 1 & 1 & 14 & 5 & 13 & 2 & 5 \\
\hline+14 & 1 & 9 & 4 & 13 & 3 & 8 & 0 & 3 \\
\hline+15 & 0 & 1 & 0 & 0 & 5 & 18 & 3 & 14 \\
\hline+16 & 1 & 2 & 4 & 10 & 3 & 19 & 0 & 2 \\
\hline Note: (-) symbolises a reversed item, see the Standard' Belief Instrument in Appendix A \\
\hline
\end{tabular}

Table 2: Frequency count by years of teaching per item on the SBI 
education programmes had higher scores on the SBI with regards to their beliefs about the NCTM Standards over the teachers who had been teaching more than five years.

\section{Findings, Conclusions, and Recommendations}

The SBI was used to see whether new math teachers who have recently graduated from a mathematics teacher education programme had beliefs about the Standards that produced higher mean scores than teachers who have been teaching for five years or more. The research hypothesis addressed was: There is a significant difference between the Standards' Beliefs Instrument scores of teacher with five or less years of teaching experience and those of teachers with five or more years of teaching experience.

It was reported that the overall mean on the SBI for the teachers was 43.07. This in itself may raise the question of whether the teachers in the sample actually have a high level of agreement about using the NCTM Standards. One would hope that a math teacher would be familiar with the Standards. This study indicated this sample of math teachers scored at the 67th percentile in agreement with the Standards according to the SBI. The possible range of scoring on the SBI is from 16 to 64 . The mean of 43.07 from the sample of teachers may suggest that, overall; the teachers do not display a high level of knowledge or beliefs about using the Standards. This in itself may be important to recognise. More pre-service and in-service training for math teacher about the Standards may be necessary. In fact, in some states in the USA like Florida it may be a real concern. While Florida is trying to raise standards for students by initiating the Sunshine State Standards, the need to raise standards for teachers may be as important as focussing on its students' math performance. Perhaps ongoing graduate coursework/in-service training should be compulsory to ensure that teachers stay abreast to the new research and "best practices" as they apply to teaching mathematics.

The hypothesis was tested using an ANOVA. The aspects of the study relating to teachers' beliefs about the Standards and the years they have been teaching showed little evidence that teachers who have been teaching for less than five years agree with using the NCTM Standards according to the SBI more than teachers with five or more years of teaching experience. It is, however, noteworthy to mention that the teachers with fewer years of experience, who for the most part are recent college graduates, had mean scores on the SBI higher than teachers with more than four years of experience.
This may be attributed to the dissemination of the Standards during preservice training. The Standards (NCTM 1989 \& 2000) documents are fairly new texts providing guidelines for math teachers, and in fact many teachers noted in their surveys that they were unfamiliar with them.

\section{Recommendations}

Based on findings and insights, gained in this study, the following recommendations for future research are suggested

1. Conduct a similar study emphasising more qualitative research methods, where observations are made of teaching methodologies in mathematics instruction, to gain greater insight into the reasons for teachers' beliefs and their responses and attitudes to the Standards.

2. Conduct more research related to how and whether teachers' beliefs influence their actual teaching practices and methodologies. Along with this look into why teachers have adopted either a pro/anti/ambivalent stance toward the NCTM Standards and/or other best practices in the teaching of mathematics.

3. Conduct in-service and pre-service training on the NCTM Standards which is ongoing, and evaluate its effects on the classroom learning as well as teachers' beliefs toward the Standards.

4. Examine countries and states which require continued graduate work and in-service for competence and understanding of "best practices" in the teaching of mathematics, and see how this correlates with student performance in mathematics.

5. Examine how various countries are now using and implementing "best practices" and math curricula based on outcomes from the Third International Mathematics and Science Study (TIMSS). Focus on what progress and speed of change recommendations and findings from this international study have had on teacher instruction and the student achievement levels in mathematics.

\section{Summary}

NCTM (1991, p.6) says: "Classrooms should be mathematics communities that thrive on conjecturing, inventing, and problem solving, and that build mathematical confidence." Williams (1988, p.101) sums up a humane strategy that all math educators can use:

To paraphrase a Chinese proverb:

Tell me mathematics, and I will forget; show me mathematics, and I may remember; 
involve me...and I will understand mathematics.

If I understand mathematics, I will be less likely to have math anxiety. And if I become a teacher of mathematics, I can thus begin a cycle that will produce less math-anxious students for generations to come.

It can be seen in this study that although the NCTM Standards were published in 1989 and updated in 2000, implementation of the Standards has not yet been fully achieved. Many teachers are not familiar with NCTM or the Standards documents. It is interesting to consider how the standards/guidelines will in the new 2000 version be implemented and how this may influence pedagogy. It appears that math educators at all levels, along with national and state school officials, need to stress the importance of their contents and continue to provide training and dissemination of these very significant documents. Conventional wisdom and research suggests that teacher change and buy-in is very slow. The research from the Third International Mathematics and Science Study (TIMSS) indicates how small our world has become in the area of mathematics education (TIMSS Video Mathematics Research Group, 2003; Schmidt, 1998). Educators are now looking at global perspectives on best practices and curriculum issues in the teaching of mathematics. NCTM and TIMSS have provided excellent guidance for the U.S. and international educators on the improvement of mathematics education. As for any country, however, teacher change and adherence to such standards and best practices, along with buy-in, are often slow processes.

\section{References}

APPLE M. W., 1992, “Thinking more politically about the challenges before us: A response to Romberg" in Journal for Research in Mathematics Education, 23(5), pp. 438-40

BALL, D.L.,\& WILSON, S.M. (1990). Knowing the subject and learning to teach it; Examining assumptions about becoming a mathematics teacher. East Lansing, MI: Michigan State University (ERIC Document Reproduction Service No. ED 323 207)

BUSH, W. S., LAMB, C. E., \& ALSINA, A., 1990, "Gaining certification to teach secondary mathematics: a story of three teachers from other disciplines" in Focus on Learning Problems in Mathematics, 12(1), pp. 41-60

COONEY, T. J., \& FRIEL, S. N., 1992, "Implementing the professional standards for teaching mathematics" in Arithmetic Teacher, 39(6), pp. 62-64

EDGERTON, R. T., 1992, A description of the assessment practices of teachers who have begun to implement the instructional practices suggested in the NCTM Standards document, paper presented at the Annual Meeting of the American Educational Research Association, San Francisco, CA

FARRELL, M. A., \& HOUSE, P. A., 1994, "Let the mathematics-science connection break the mold in teacher preparation” in Mathematics Teacher, 87(4), p. 289

FENNEMA, E., \& FRANKE, M., 1992, “Teacher’s knowledge and its impact” in D. Grouws (Ed.), Handbook of Research on Mathematics Teaching and Learning, pp. 147-64, New York: Macmillan Publishers

FERRINI-MUNDY, J., April 1986, Mathematics teachers' attitudes and beliefs: Implications for in-service education, paper presented at the annual meeting of the American Education Research Association, San Francisco, CA

FULLAN, M., 1983, The meaning of education change, New York, New York: Teachers College Press.

FURNER, J. M., 1996, Mathematics teachers' beliefs about using the National Council of Teachers of Mathematics Standards and the relationship of these beliefs to students' anxiety toward mathematics, unpublished doctoral dissertation, University of Alabama

GADANIDIS, G., 1991, “Deconstructing constructivism” in Mathematics Teacher, 87(2), pp. 91-94

KERR, D. R., \& LESTER, F. K., 1982, “A new look at the professional training of secondary school mathematics teachers" in Educational Studies in Mathematics, 13, pp. 431-441

KESSLER, R., 1985, Teachers' instructional behaviour related to their conceptions of teaching and mathematics and their level of dogmatism: Four case studies, Dissertation Abstracts International, 46A, 2606A

LUBIENSKI, S. L., 2000(a), "Who's counting? A survey of mathematics education research 19821998” in Journal for Research in Mathematics Education, 31(5), pp. 626-634

LUBIENSKI, S. L. 2000(b), "Problem solving as a means toward mathematics for all: An exploratory look through a class lens” in Journal for Research in Mathematics Education, 31(4), pp. 454-483 
LUBINSKI, C. A., 1994, “The influence of teachers' beliefs and knowledge on learning environments" in Arithmetic Teacher, 41(8), pp. 476-479

MCGALLIARD, W. A., Jr., 1983, Selected factors in the conceptual systems of geometry teachers: Four case studies, Dissertation Abstracts International, 44A, 1364

MEYER, R. A., 1980, Attitudes of elementary teachers toward mathematics, ERIC Document Reproduction Service No. ED 190388

NATIONAL COUNCIL OF TEACHERS OF MATHEMATICS, 1989, Curriculum and evaluation standards for school mathematics Reston, VA: Author

NATIONAL COUNCIL OF TEACHERS OF MATHEMATICS, 1991, Professional standards for teaching mathematics, Reston, VA: Author

NATIONAL COUNCIL OF TEACHERS OF MATHEMATICS, 2000, Principles and standards for school mathematics: Discussion, Reston, VA: Author

NATIONAL COUNCIL OF TEACHERS OF MATHEMATICS (NCTM) \& ASSOCIATION FOR SUPERVISION AND CURRICULUM DEVELOPMENT (ASCD), 1991, A guide for reviewing school mathematics programs, Reston, VA: Author

O’LAUGHLIN, M., April 1990, Teachers' ways of knowing: A journal study of teacher learning in a dialogue and constructivist learning environment, paper presented at the annual meeting of the Association of Teacher Educators, Boston, MA., ERIC Document Reproduction Service No. ED 327477

PAJARES, M. F., 1992, “Teachers' beliefs and educational research: Cleaning up a messy construct” in Review of Education Research, 62, pp. 1-40

PARKER, R. E., 1991, "Implementing the curriculum and evaluation standards: What will implementation take?” in Mathematics Teacher, 84(6), pp. 442-478

REYES, L. H., April 1987, Describing the affective domain: Saying what we mean, paper presented at the research pre-session to the annual meeting of the National Council of Teachers of Mathematics, Anaheim, CA

SARASON, A., 1993, The case for change, San Francisco, CA: Jossey-Bass Inc. SAS Institute, Inc. (1985). SAS user's guide: Statistics, version 5. Cary, NC: Author

SCHMIDT, W. H., 1998, Changing mathematics in the U.S.: policy implications from the third international mathematics and science study, presentation at the 76th Annual meeting of the
National Council of Teachers of Mathematics, Washington, D.C., April 3, 1998

SILVER, E. A., 1985, "Research on teaching mathematical problem solving: Some underrepresented themes and needed directions" in E. A. Silver, (Ed.), Teaching and learning mathematical problem solving: Multiple research perspectives, pp. 247-266, Hillsdale, NJ: Erlbaum

SIMON, M. A., 1995, "Reconstructuring mathematics pedagogy from a constructivist perspective" in Journal for Research in Mathematics Education, 26(2), pp. 114-145

SKEMP, R. R., 1979, "Goals of learning and qualities of understanding" in Mathematics Teaching, 88, pp. 44-49

SMITH, M. K., 1994, HumblePi, Amherst, NY: Promtheus Books

SPIELBERGER, C. D., \& VAGG, P., 1995, Test anxiety, Washington, DC: Taylor \& Francis Publishers

STEEN, L. A., 1990, The shoulders of giants, Washington, DC: National Academy Press

STIGLER, J.W. AND HIEBERT, J., 1999, The Teaching Gap: Best Ideas from the World's Teachers for Improving Education in the Classroom, New York: Free Press

STOUDEMIRE, A., 1994, Clinical psychiatry for medical students, Philadelphia, PA: Lippincott

THOMPSON, A., 1992, “Teachers' beliefs and conceptions: A synthesis of research" in D. Grouws (Ed.), Handbook of research on mathematics teaching and learning, pp. 127-46 New York: Macmillan

THOMPSON, A. G., 1984, "The relationship of teachers' conceptions of mathematics and mathematics teaching to instructional practice" in Educational Studies in mathematics, 15, pp. 105-127

TIMSS Video Mathematics Research Group, 2003, "Understanding and improving mathematics teaching: Highlights from the TIMSS 1999 video study" in Phi Delta Kappan, 84(10), pp. 768-779

WARWICK, D. P., 1973, "Survey research and participant observation: A benefit-cost analysis" in D. P. Warwick \& S. Osherson (Eds.), Comparative Research Methods: pp. 189-203, Englewood Cliffs, NJ: Prentice-Hall

WEISS, I. R., 1990, "Mathematics teachers in the United States" in International Journal of Educational Research, 14, pp. 139-155

WELLS, D., 1994, "Anxiety, insight and appreciation” in Mathematics Teaching, 147, 8 
Implementing the NCTM Standards: A Slow Process

WIESCH ENBERG, A. A., 1994, “Overcoming conditioned helplessness in mathematics" in College Teaching, 42(2), p. 51

WILLIAMS, W. V., 1988, "Answers to questions about math anxiety" in School Science and Mathematics, 88(2), pp. 95-104
ZOLLMAN, A., \& MASON, E., 1992, "The Standards' Beliefs Instrument (SBI): Teachers' beliefs about the NCTM Standards" in School Science and Mathematics, 92(7), pp. 359-364 
Appendix A: The Standards’ Belief Instrument

Thank you for filling out this instrument for me!

Directions: Complete the following survey by answering each question. Please do not include your name.

\section{A. Demographic information}

\begin{tabular}{|c|c|c|c|c|c|}
\hline A. 1 & $\begin{array}{l}\text { The number of years you have been } \\
\text { teaching: }\end{array}$ & 4 or less & $5-10$ & $11-20$ & $\begin{array}{l}\text { More than } \\
20\end{array}$ \\
\hline A. 2 & $\begin{array}{l}\text { The number of years you have been } \\
\text { teaching math: }\end{array}$ & 4 or less & $5-10$ & $11-20$ & $\begin{array}{l}\text { More than } \\
\quad 20\end{array}$ \\
\hline A.3 & Your highest educational level: & Bachelor's & Master’s & $\begin{array}{l}\text { Beyond } \\
\text { Master's }\end{array}$ & Doctorate \\
\hline A. 4 & $\begin{array}{l}\text { What math grade level have you taught at } \\
\text { the longest? }\end{array}$ & Elementary & $6-8$ & $9-10$ & $\begin{array}{l}11-12 \text { or } \\
\text { higher }\end{array}$ \\
\hline A. 5 & $\begin{array}{l}\text { What teaching credentials do you hold for } \\
\text { teaching math? (mark all that apply) }\end{array}$ & Elem. Math & $\begin{array}{l}\text { Middle } \\
\text { Math }\end{array}$ & Secondary & Other \\
\hline A. 6 & College Undergraduate major: & Math Ed. & Math & Liberal Arts & Other \\
\hline A.7 & Your age range: & $\begin{array}{l}24 \text { or } \\
\text { younger }\end{array}$ & $25-35$ & $36-45$ & 46 or older \\
\hline A.8 & Familiarity with the NCTM Standards: & None & Little & Some & $\begin{array}{c}\text { A great } \\
\text { deal }\end{array}$ \\
\hline A.9 & $\begin{array}{l}\text { Number of classes you teach of math a } \\
\text { day: }\end{array}$ & 3 or less & 4 & 5 & 6 or more \\
\hline A. 10 & $\begin{array}{l}\text { What would you estimate is the current } \\
\text { rate of your students' math anxiety: }\end{array}$ & None & Little & Some & $\begin{array}{c}\text { A great } \\
\text { deal }\end{array}$ \\
\hline A.11 & $\begin{array}{l}\text { Do you think students these days have } \\
\text { more math anxiety then they did in the } \\
\text { past? }\end{array}$ & Yes & No & The same & \\
\hline A.12 & Your Gender: & Male & Female & & \\
\hline
\end{tabular}


B. Standards’ Belief Instrument (Zollman \& Mason, 1992)

Directions: Shade in the answers that best describe your feeling about the following statements on the scantron grid provided. Use the following code:

$1=$ strongly disagree $\quad 2=$ disagree $\quad 3=$ agree 4 = strongly agree

\begin{tabular}{|c|c|c|c|c|c|}
\hline 1 & $\begin{array}{l}\text { Problem solving should be a SEPARATE, DISTINCT part of the } \\
\text { mathematics curriculum. }\end{array}$ & 1 & 2 & 3 & 4 \\
\hline 2 & $\begin{array}{l}\text { Students should share their problem-solving thinking and approaches } \\
\text { WITH OTHER STUDENTS. }\end{array}$ & 1 & 2 & 3 & 4 \\
\hline 3 & $\begin{array}{l}\text { Mathematics can be thought of as a language that must be } \\
\text { MEANINGFUL if students are to communicate and apply mathematics } \\
\text { productively. }\end{array}$ & 1 & 2 & 3 & 4 \\
\hline 4 & $\begin{array}{l}\text { A major goal of mathematics instruction is to help children develop the } \\
\text { beliefs that THEY HAVE THE POWER to control their own success in } \\
\text { mathematics. }\end{array}$ & 1 & 2 & 3 & 4 \\
\hline 5 & $\begin{array}{l}\text { Children should be encouraged to justify their solutions, thinking, and } \\
\text { conjectures in a SINGLE way. }\end{array}$ & 1 & 2 & 3 & 4 \\
\hline 6 & $\begin{array}{l}\text { The study of mathematics should include opportunities of using } \\
\text { mathematics in OTHER CURRICULUM AREAS. }\end{array}$ & 1 & 2 & 3 & 4 \\
\hline 7 & $\begin{array}{l}\text { The mathematics curriculum consists of several discrete strains such as } \\
\text { computation, geometry, and measurement which can be best taught in } \\
\text { ISOLATION. }\end{array}$ & 1 & 2 & 3 & 4 \\
\hline 8 & $\begin{array}{l}\text { In K-4 mathematics, INCREASED emphasis should be given to reading } \\
\text { and writing numbers SYMBOLICALLY. }\end{array}$ & 1 & 2 & 3 & 4 \\
\hline 9 & $\begin{array}{l}\text { In K-4 mathematics, INCREASED emphasis should be given to use of } \\
\text { CLUE WORDS(key words) to determine which operations to use in } \\
\text { problem solving. }\end{array}$ & 1 & 2 & 3 & 4 \\
\hline 10 & $\begin{array}{l}\text { In K-4 mathematics, skill in computation should PRECEDE word } \\
\text { problems. }\end{array}$ & 1 & 2 & 3 & 4 \\
\hline 11 & $\begin{array}{l}\text { Learning mathematics is a process in which students ABSORB } \\
\text { INFORMATION, storing it easily retrievable fragments as a result of } \\
\text { repeated practice and reinforcement. }\end{array}$ & 1 & 2 & 3 & 4 \\
\hline 12 & $\begin{array}{l}\text { Mathematics SHOULD be thought of as a COLLECTION of concepts, } \\
\text { skills algorithms. }\end{array}$ & 1 & 2 & 3 & 4 \\
\hline 13 & $\begin{array}{l}\text { A demonstration of good reasoning should be regarded EVEN MORE } \\
\text { THAN students' ability to find correct answers. }\end{array}$ & 1 & 2 & 3 & 4 \\
\hline 14 & $\begin{array}{l}\text { Appropriate calculators should be available to ALL STUDENTS at ALL } \\
\text { TIMES. }\end{array}$ & 1 & 2 & 3 & 4 \\
\hline 15 & Learning mathematics must be an ACTIVE PROCESS. & 1 & 2 & 3 & 4 \\
\hline 16 & $\begin{array}{l}\text { Children ENTER KINDERGARTEN with considerable mathematical } \\
\text { experience, a partial understanding of many mathematical concepts, and } \\
\text { some important mathematical skills. }\end{array}$ & 1 & 2 & 3 & 4 \\
\hline
\end{tabular}

